\title{
Muslim Women's Work Participation in India
}

\author{
Nahid Sarikhani \\ Department of Sociology, Mysore University, Manasagotri, Mysore, Karnataka, India
}

KEYWORDS Muslim; women; work participation; India; literacy

\begin{abstract}
The present study aims at investigating "Muslim women's work participation in India "based on: population census in 2001. In this study has been used of "descriptive research". Results have indicated that Muslim constitutes 13.4 percent of India's population. Indeed, India has the second largest Muslim population in the world. Sex ratio among Muslim population at national level is 936 . Illiterate rate of Muslim women is high and they have not been able to take full advantage in society. There also exists a wide gap between the works participation rate of males and females. In additional, a significant part of Muslim women are recorded as unskilled work sources in the country.
\end{abstract}

\section{INTRODUCTION}

Islam holds that woman is a human being and she has a soul similar to that of man. Thus, men and women were equal to each other in their origin, their abode as well as in their place of return and were as such entitled to similar and equal rights. But, Islam came to India in a particular form, especially with purdah, which is synonymous with high status and respectability. Its enforcement became so pervasive that any woman found without a veil was ruled as shameless and outside of decent society (Upreti, 2000).

Early marriage is also very common among the Muslim. It creates problems in acquiring education for women. After marriage, Muslim women are not allowed to move out without escort; as a result, they cannot continue their education and other economic spheres after marriage. Divorce was commonly practiced; Muslim husbands quite frequently used it. Polygamy was also prevalent among the Muslim, especially among high class Muslim. Women of high and well to do families are secluded by purdah, though the women from poorer sections had to work outside their houses for their livelihood, the purdah system isolated Muslim women from the outer world and confined them to the four walls of their houses. It has also restricted the Muslim women from making significant economic contributions, either towards hers' own independence or towards the economic expenditure of the family.

Address for correspondence:

Nahid Sarikhani

$380,2^{\text {nd }}$ Main, 3 Rd Stage, $9^{\text {th }}$ Cross, Gokulam, Mysore2, Karnataka, India

Telephone: 9902419179, E-mail: na_s_16@yahoo.com
They are always oppressed and exploited. Their jobs, is to manage the house and rear the children. (Urmila, 1988) Since the social norms have not been uniform in all sections of society, two contrary trends are clearly discernible with respect to female work participation: (1) active participation of some women in productive activities, and (2) seclusion or abstention of some women from work. (Dak, 1988) The work participation rates of women and men are strongly influenced by socio-economic and biological factors.

In India many studies indicated that Hindu and Christian women work participation is higher than other religions; especially Muslim working women are very low. As per the 2001 census, the work participation rate of women is only 25.6percent in India, the position of Muslim women is worse. As the work participation rate of these women in India is 14.1 percent.

In the study, the author attributes analyzing the socio-economic aspects of the Muslim working women from the scope of statistical center of India reflected by general census of 2001 in India.

\section{OBSERVATIONS AND DISCUSSION}

According to the 2001census, Muslim constitutes 13.4 percent of India's population. Indeed, India has the second largest Muslim population in the world. Table 1 shows, population of Muslim is steadily increasing, as unadjusted growth rate would increase from 22.9 percent to 36 percent during 1981-2001. Sex ratio among Muslim population at national level is 936 which is just above the national average of 933 for all religions that it probably presents the position 
Table 1: Population and proportion of Muslim population by sex, sex ratio, percentage increase, India 1981-2001

\begin{tabular}{lccccc}
\hline Census Year & Persons & Males & Females & Sex ratio & Percentage Increase \\
\hline 2001 & $138,188,240$ & $71,374,134$ & $66,814,106$ & 936 & $(1991-2001)=36.0$ \\
1991 & $101,596,057$ & $52,631,365$ & $48,964,692$ & 930 & $(1981-1991)=34.5$ \\
1981 & $75,512,439$ & $38,989,763$ & $36,522,676$ & 937 & $(1971-1981)=22.9$ \\
\hline
\end{tabular}

Source: - Census of India 2001.2004. The First report on Religion Data. New Delhi: Registrar General \& Census Commissioner.

- Census of India 1991.1995. Karnataka. Series 11. part IV-B (ii). Religion. (Table c-9). New Delhi: Director of Census Operations Karnataka.

- Census of India 1981.1985. Karnataka. Series 9. Household Population by Religion of Head of Household Karnataka. New Delhi: Director of Census Operations Karnataka.

Table 2: Literates rate of Muslim by residence, sex, India $\mathbf{- 2 0 0 1}$

\begin{tabular}{|c|c|c|c|c|}
\hline \multirow[t]{2}{*}{ Residence } & \multicolumn{2}{|c|}{ Literates } & \multicolumn{2}{|c|}{ Illiterates } \\
\hline & Male & Female & Male & Female \\
\hline Total & $39,248,081$ & $27,148,553$ & $18,846,513$ & $27,052,034$ \\
\hline Percent & 67.6 & 50.1 & 32.4 & 49.9 \\
\hline Rural areas & $22,624,881$ & $14,742,834$ & $13,678,138$ & $19,818,594$ \\
\hline Percent & 62.3 & 42.7 & 37.7 & 57.3 \\
\hline Urban areas & $16,623,200$ & $12,405,719$ & $5,168,375$ & $7,233,440$ \\
\hline Percent & 76.3 & 63.2 & 23.7 & 36.8 \\
\hline
\end{tabular}

Source: Census of India 2001.2004. The First report on Religion Data. New Delhi: registrar general \& census commissioner.

Table 3: Work participation rate of Muslim population by sex, sex ratio, and residence: India, 2001

\begin{tabular}{lrrrr}
\hline Residence & Persons & \multicolumn{1}{c}{ Males } & Females & Sex ratio \\
\hline India & $43,296,093$ & $33,886,213$ & $9,409,880$ & 278 \\
Percent & 100 & 78.3 & 21.7 & 352 \\
Rural areas & $29,151,524$ & $21,559,619$ & $7,591,905$ & 26 \\
Percent & 100 & 74 & $1,817,975$ & 147 \\
Urban areas & $14,144,569$ & $12,326,594$ & 12.9 & \\
Percent & 100 & 87.1 &
\end{tabular}

Source: Census of India 2001.2004. The First report on Religion Data. New Delhi: Registrar General \& Census Commissioner.

of women has worsened considerably, a decline in the sex ratio due to absolute condition of health and survival for women. What it means is that the gap between male and female survival may have increased.

Education is an indispensable means for helping the Muslim women out of their economic misery because economic dependency is another factor contributing to the low status of women. As per 2001 census, literacy rate for the population age of 7 years and above in the country as a whole stands at 64.8 percent. Muslim literacy rate is lower than the national average literacy rate at 59.1 percent. In the rural areas, literacy rate are 52.7 percent and in the urban areas are 70.1 percent in India. (Census of India, 2001)

Also, of the total Muslim population age of 7 years and over, 40.9 percent are illiterate. This rate in rural areas $(47.3 \%)$ exceeds the urban areas
(29.9\%). In addition, the figures at table 2 shown, rate among the Muslim women 49.9 percent is higher than the Muslim men $(32.4 \%)$ and this pattern, similarly blinks among rural areas (male is 37.7 and female is $57.3 \%$ ) and urban areas (male is $23.7 \%$ and female is $36.8 \%$ ). The statistics above indicate Muslim women have not been able to take full advantage in the society.

As a matter of fact, available literature indicates that there is a close relationship between the spread of female education on the one hand and the development status on the other. As, Safia Iqbal(1986) says in her book (women and Islamic law) that the greatest problems discerned by the Muslim women are that women lack proper knowledge of their faith, and that this is why Muslim men sometimes mistreat their women. (Sharma, 2002)

The work participation rate is defined as percentage of total worker (main and marginal) 
Table 4: Work participation rate of Muslim communities by sex: India, 2001

\begin{tabular}{lrrr}
\hline $\begin{array}{l}\text { India/States/ } \\
\text { Union territories }\end{array}$ & Total & Male & Female \\
\hline India & & & \\
Jammu \& Kashmir & 31.3 & 47.5 & 14.1 \\
Himachal Pradesh & 35.1 & 47.2 & 22.0 \\
Punjab & 45.9 & 56.3 & 32.9 \\
Chandigarh & 40.3 & 56.7 & 19.7 \\
Uttaranchal & 39.6 & 60.6 & 7.3 \\
Haryana & 27.5 & 46.0 & 6.4 \\
Delhi & 37.8 & 45.2 & 29.4 \\
Rajasthan & 30.9 & 51.3 & 4.8 \\
Uttar Pradesh & 34.7 & 46.7 & 21.7 \\
Bihar & 29.1 & 44.6 & 12.4 \\
Sikkim & 30.9 & 45.8 & 15.1 \\
Arunachal Pradesh & 53.4 & 70.9 & 13.6 \\
Nagaland & 45.0 & 61.6 & 18.4 \\
Manipur & 43.6 & 60.5 & 16.2 \\
Mizoram & 36.8 & 43.7 & 29.6 \\
Tripura & 76.1 & 86.5 & 37.9 \\
Meghalaya & 29.2 & 46.2 & 11.2 \\
Assam & 31.4 & 48.9 & 11.8 \\
Weast Bengal & 29.1 & 47.2 & 9.7 \\
Jharkhand & 32.9 & 50.5 & 14.0 \\
Orissa & 31.6 & 43.5 & 18.8 \\
Chhattisgarh & 26.9 & 45.9 & 6.8 \\
Madhya Pradesh & 32.3 & 48.5 & 15.0 \\
Gujarat & 32.8 & 47.6 & 16.9 \\
Daman \& Diu & 32.7 & 51.1 & 13.0 \\
Dadra \& Nagar Haveli & 37.5 & 61.6 & 7.3 \\
Maharashtra & 42.5 & 64.3 & 11.0 \\
Andhra Pradesh & 32.4 & 50.0 & 12.7 \\
Karnataka & 33.8 & 50.1 & 16.8 \\
Goa & 36.4 & 52.1 & 19.9 \\
Lakshadweep & 34.3 & 54.6 & 10.9 \\
Kerala & 23.0 & 38.9 & 7.1 \\
Tamil Nadu & 23.2 & 42.0 & 5.9 \\
Pondicherry & 31.8 & 52.0 & 11.9 \\
Andaman \& Nicobar Islands & 24.4 & 46.5 & 4.2 \\
& 34.5 & 53.8 & 12.1 \\
\hline Note: & & & \\
\hline
\end{tabular}

Note: 1. Population figures for India and Manipur exclude those of Mao Maram, Paomata and Purul subdivisions of Senapati district of Manipur.

Source: Census of India 2001.2004. The First report on Religion Data. New Delhi: registrar general \& census commissioner. to total population. This is often considered as a very crude measure since this does not take into account the age structure of the population.

According to the census of 2001, in India, of the total population of $138,188,240$ the number of Muslim returned as workers is 43,396,093. In other words, 31.3 percent of the Muslim populations of India constitute workers. Of these workers, 33,886,213 are males and 9,409,880 are females (Table3), sex ratio in between them are 278 , in other words, the 2001 census has recorded a Muslim working population sex ratio of 278 Muslim women per 1000 Muslim males. Amajority of Muslim workers $(21,559,619)$ in the country are employed in the rural areas, primarily as laborers and cultivators and the number of Muslim women is 7,591,905. Sex ratio of Muslim women worker has risen in rural areas (352) than to total country (278). Of course, in urban areas, has decreased sex ratio of Muslim women (147) than to the total of country.

According to table 4, the highest work participation rate of Muslim women over 30 percent has been returned from Himachal Pradesh (32.9\%) and Mizoram (37.9\%). The lowest work participation rate of Muslim women less 10 percent has been recorded in 9 states and Union Territories. The rest of the work participation rate of Muslim women of over 10 percent to 20 percent has been recorded in 21 states and Union Territories. In general, with regard to the above data, there exists a wide gap between the works participation rates of males and females.

On the other hand, results have shown, of the total Muslim women population of $66,814,106$, the number of Muslim women recorded as house wife is $57,404,226$ or 85.9 percent, and only 14.1 percent of Muslim women are workers. Thus the rural and urban areas are 17.5 percent and 7.7 percent respectively. Table

Table 5: Work participation rate of Muslim population by category of work, sex, India, 2001

\begin{tabular}{lrrrrr}
\hline Sex & \multicolumn{1}{c}{$\begin{array}{l}\text { Total } \\
\text { workers }\end{array}$} & Cultivators & $\begin{array}{l}\text { Agricultural } \\
\text { labourers }\end{array}$ & $\begin{array}{l}\text { Household } \\
\text { industry workers }\end{array}$ & $\begin{array}{l}\text { Other } \\
\text { workers }\end{array}$ \\
\hline T & $43,296,093$ & $8,979,686$ & $9,545,976$ & $3,520,467$ & $21,249,964$ \\
& 100 & 20.7 & 22.1 & 8.1 & 49.1 \\
M & $33,886,213$ & $6,910,438$ & $6,645,706$ & $1,708,121$ & $18,621,948$ \\
& 100 & 20.4 & 19.6 & 5 & 55 \\
F & $9,409,880$ & $2,069,248$ & $2,900,270$ & $1,812,346$ & $2,628,016$ \\
& 100 & 22 & 30.8 & 19.3 & 27.9 \\
\hline
\end{tabular}

Source: Census of India 2001.2004. The First report on Religion Data. New Delhi: Registrar General \& Census Commissioner. 
5 is shown; a majority of Muslim women workers in India are employed in the rural areas, primarily as agricultural laborers and cultivators. In the urban areas, a part of the Muslim women workers are employed in the unorganized sector, i.e. in household industries, petty trades and services, buildings and construction etc.

In general, results have indicated that exist a wide gap between the works participation rate of males and females. According to social situation of Muslim women in India, we should implement proper programmes in related to improve and to increase aware level of Muslim women about equal status of women with men and this belief is translated into actual practice through several institutions, customs and practices. It is essential to implement legislations that protect Muslim women's rights by advertisement, plays, films etc.

\section{REFERENCES}

Census of India 2001.2004. The First Report on Religion Data. New Delhi: Registrar General \& Census Commissioner.

Census of India 1991. 1995. Karnataka. Series 11. part IV-B (ii). Religion: Table c-9. Mysore: Director of Census Operations Karnataka.

Census of India 1981.1985. Karnataka. Series 9. Household Population by Religion of Head of Household Karnataka. Mysore: Director of Census Operations Karnataka.

Dak, T.M. 1988. Women and Work in Indian Society. Delhi: Discovery Publishing House.

Sharma, A. 2002. Women in Indian Religions. New Delhi: Oxford University Press.

Upreti, H.C and Nandini Upreti. 2000. Women and Problems of Gender Discrimination. India: Pointer Publishers.

Urmila, P. 1988. Problems of Working Women in India. Delhi: Discovery Publishing House. 